\title{
A STUDY OF THE ELASTIC BEHAVIOUR PRESENTED BY DIFFERENT TYPES OF SEDIMENTARY ROCKS
}

\author{
Ana Paula 0. Castro ${ }^{1}$, Eliane da Costa Alves ${ }^{2}$ and Guilherme F. Vasquez ${ }^{3}$
}

\begin{abstract}
The purpose of this paper is to study the elastic behavior of the different kinds of sedimentary rocks from outcrops of the Middle-West region of the United States of America, among those, Berea sandstone from Bedford formation (Ohio), Indiana limestone from Salem formation (Indiana) and Silurian dolomite from Thornton formation (Illinois). To do so, it has been made in the Laboratório de Fisica de Rochas from Cenpes (Centro de Pesquisas e Desenvolvimento da Petrobras), measurements of porosity, density and elastic wave propagation velocity presented by each type of studied rock. The wave propagation velocities were estimated by measuring the transit time ultrasonic pulses transmitted through the samples. From the results obtained, it was possible to compare the measured velocities with predictions from theoretical models, as well as to observe correlations between the petrophysical properties of rocks and its seismic behavior. Understanding these correlations helps to improve the interpretation of geophysical measurements and to improve the seismic method, which in turn has a direct impact on exploration and development activities reservoirs.
\end{abstract}

Keywords: seismic velocities, elastic properties, sedimentary rocks.

RESUMO. 0 objetivo deste trabalho é estudar o comportamento elástico de diferentes tipos de rochas sedimentares provenientes de afloramentos da região CentroOeste dos Estados Unidos da América, entres estas, o arenito Berea da formação Bedford (Ohio), o calcário Indiana da formação Salem (Indiana) e o dolomito Silurian da formação Thornton (Illinois). Para tanto, foram realizadas, no Laboratório de Física de Rochas do Cenpes (Centro de Pesquisas e Desenvolvimento da Petrobras), medidas de porosidade, densidade e de velocidades de propagação das ondas elásticas apresentadas por tipo de rocha estudada. As velocidades de propagação das ondas foram determinadas medindo-se o tempo de trânsito de um pulso ultrassônico de alta frequência transmitido através das amostras. A partir dos resultados obtidos, foi possível comparar as velocidades medidas com as previsões feitas a partir de modelos teóricos, assim como foi possível observar correlações existentes entre as propriedades petrofísicas das rochas e o seu comportamento sísmico. 0 entendimento dessas correlações contribui para a melhoria da interpretação de medidas geofísicas e para o aprimoramento do método sísmico, que por sua vez, tem impacto direto nas atividades de exploração e desenvolvimento de reservatórios.

Palavras-chave: velocidades sísmicas, propriedades elásticas, rochas sedimentares.

\footnotetext{
1 Universidade Federal Fluminense - UFF/Petrobras, Av. Horácio Macedo, 950, Radial 3, Laboratório 361, Cidade Universitária, 21941-915 Rio de Janeiro, RJ, Brazil. Phone: +55(21) 2162-6915 - E-mail: anapaulacastro@petrobras.com.br

2Universidade Federal Fluminense - UFF, Av. General Nilton Tavares de Souza, s/n, Gravoatá, 24210-346 Niterói, RJ, Brazil. Phone: +55(21) 2629-5928 - E-mail: elianealves@id.uff.br

3 Petrobras, Av. Horácio Macedo, 950, Expansão - Ala A - Laboratório A07, Cidade Universitária, 21941-915 Rio de Janeiro, RJ, Brazil. Phone: +55(21) 2162-6457

- E-mail: vasquez@petrobras.com.br
} 


\section{INTRODUCTION}

Studies related to the elastic behavior of rocks have followed a growing trend in the last decades, given the importance of these researches to the understanding and interpretation of seismic and well log data. Currently, the seismic reflection methodis the most widely used technique to petroleum exploration and field development and, therefore, it becomes a fundamental tool to oil industry. In this sense, the establishment of relations between the rocks' physical properties and their seismic signatures, from laboratory measurements is determinant to the enhancement of the seismic method capabilities, allowing the accomplishment of quantitative interpretation.

Several practical applications of rock physics can be quoted to sustain the relevance of the study of these properties, such as: sonic log quality control and calibration through critical comparison of lab data and log data; estimative of the seismic wave velocities in saturated rocks with different fluids (important to simulate the seismic response and to the construction of exploratory scenarios as well asfeasibility and interpretation of seismic time lapse data sets); and the verification of the pressure dependence of the seismic properties, once in situ there are effective stress variation to which the rocks are put though during reservoir depletion (Dillon \& Vasquez, 2000; Morschbacher et al., 2010).

The scope of this paper is to study the elastic properties of different types of sedimentary rocks in laboratory and establish the relations between these properties (more specifically, the compressional and shear wave velocities) and porosity, with pressure variation and with the type of lithology. Throughout the measurement of wave velocity in some of the samples saturated with water, it was possible, also, to verify the validity of Gassmann model to these rocks, even at ultrasonic frequencies.

\section{STUDIED SAMPLES}

To accomplish this work, it has been used 15 samples of Paleozoic sedimentary rocks from outcrops of the Middle-West region in the United States of America, being those, 5 samples of Berea sandstone, 5 samples of Indiana limestone and 5 samples of Silurian dolomite.

The Berea sandstones are from the middle-north region of Ohio, in the neighborhood of Berea, next to Cleveland. It is part of the Bedford-Berea sedimentary sequence, which extends from Pennsylvania to Kentucky and it is from the Mississippian age. The traditional vision accepted is that the Berea sandstone was displaced in the Ashland and Medina districts, in fluvial channels (Hillebrand \& Coogan, 1984).
The carbonate samples ( 5 limestone samples and 5 dolomite samples) are from the states of Indiana and Illinois, respectively $335 \mathrm{Ma}$, most part of current USA was covered by shallow seas with warm waters. The skeleton and animal fragments deposition that used to live in that environment allowed the carbonates accumulation in the sea bottom and, posterior, the formation of the carbonate layers present in this region.

Table 1 provides the information on sample identification, the type of rock, the age and their formation.

\section{METHODOLOGY}

The tests to determine the rocks' elastic properties were made in the Laboratório de Física de Rochas from CENPES, Petrobras. The wave velocity measurement system allows the measurement of compressional, $\mathrm{P}\left(\mathrm{V}_{\mathrm{P}}\right)$, and shear waves, $\mathrm{S}\left(\mathrm{V}_{\mathrm{S} 1}\right.$ and $\left.\mathrm{V}_{\mathrm{S} 2}\right)$, and consist of an electronic part and a hydraulic part. The electronic part is composed by an oscilloscope and a pulse generator and the hydraulic part is composed of a hydraulic pump and a hydraulic vessel (recipient equipped with measurement metallic caps which connect to the electronic part of the system), according to Figure 1.

Inside the caps there are three piezoelectric transducers of ceramic material to the emission and reception of the electrical signal, according to the illustration on Figure 2.

The electronic part is composed by a pulse generator and a power amplifier which provides a well-known electric signal to the piezoelectric transducers of ceramic material located in the caps of the hydraulic part. The transducers transform the electronic signal into a mechanical vibration, compressive or shear waves, according to the operator's choice and vice-versa. The sample is, then, placed into the cell (measure head) and between the sample and the transducers it is placed a coupling material to distribute uniformly the acoustic waves all over the sample. After traveling through the rock sample, the mechanic vibration is received by another transducer, which converts it into an electric signal. This signal is amplified and after that, analyzed on the oscilloscope. The recorded waveforms in the oscilloscope are stored in a computer to further analysis.

The three cylindrical transducers that are built on each cap, generate, separately, a compressional wave $\left(V_{p}\right)$ and two shear waves orthogonally polarized $\left(V_{S 1}\right.$ and $\left.V_{S 2}\right)$. The velocities are determined measuring the transit time of the high frequency elastic pulse transmitted through the sample. The signal visualization in the oscilloscope indicates the transit time of the wave throughout the system with the sample. The elastic wave propagation 
Table 1 - Information about samples.

Source: Archilha et al., 2012; ISGS - Illinois State Geological Survey and USGS - U.S. Geological Survey.

\begin{tabular}{|c|c|c|c|c|}
\hline Rock & $\begin{array}{c}\text { Sample } \\
\text { (Identification) }\end{array}$ & Formation & Origin & Age \\
\hline $\begin{array}{c}\text { Berea } \\
\text { Sandstone }\end{array}$ & $\begin{array}{l}\text { BRS001 } \\
\text { BRS002 } \\
\text { BRS003 } \\
\text { BRS016 } \\
\text { BRS017 }\end{array}$ & Bedford & Ohio, USA & $\begin{array}{c}\text { Between } \\
\text { Mississipi and } \\
\text { Upper Devonian }\end{array}$ \\
\hline $\begin{array}{c}\text { Indiana } \\
\text { Limestone }\end{array}$ & $\begin{array}{l}\text { IL011 } \\
\text { IL012 } \\
\text { IL013 } \\
\text { IL016 } \\
\text { IL017 }\end{array}$ & Salem & Indiana, USA & $\begin{array}{c}\text { Middle } \\
\text { Mississippian } \\
\text { (335-340 Ma) }\end{array}$ \\
\hline $\begin{array}{l}\text { Silurian } \\
\text { Dolomite }\end{array}$ & $\begin{array}{l}\text { SD005 } \\
\text { SD006 } \\
\text { SD007 } \\
\text { SD010 } \\
\text { SD011 }\end{array}$ & Thornton & Illinois, USA & Silurian-Devonian \\
\hline
\end{tabular}

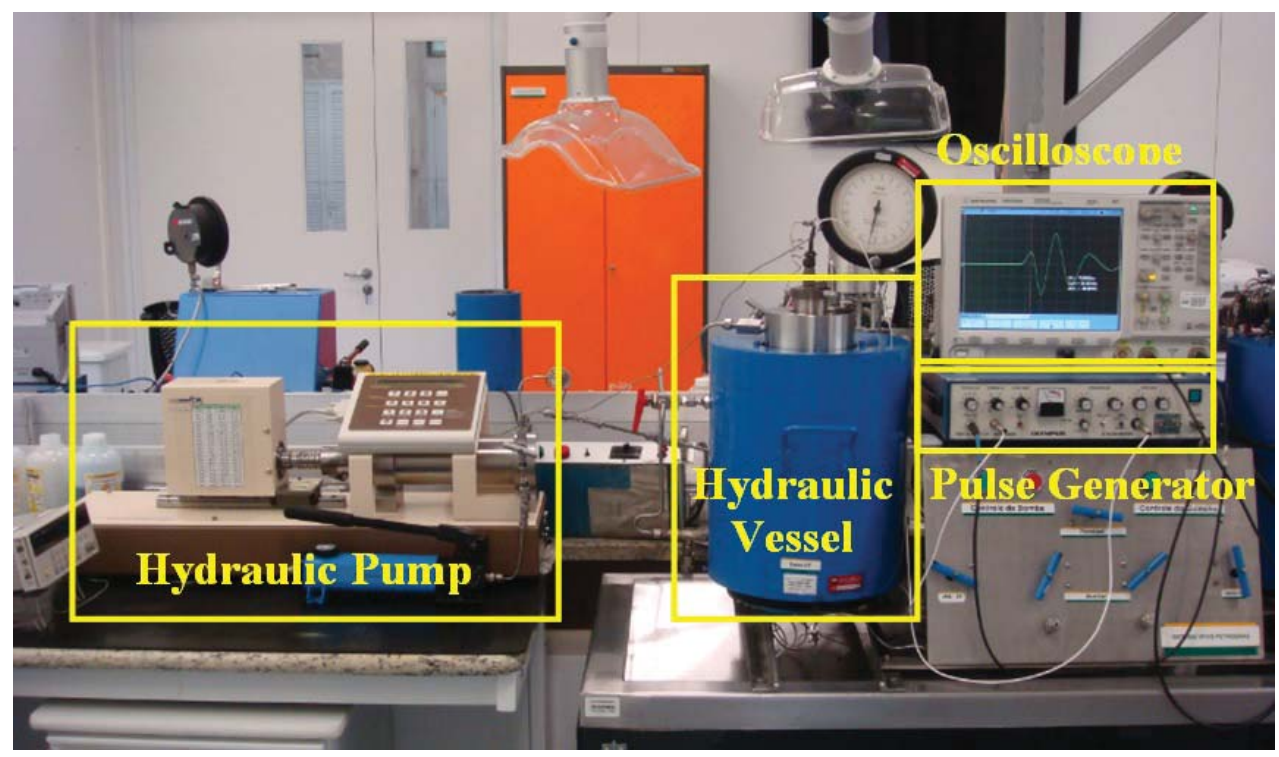

Figure 1 - Photograph of the electric wave speed propagation measurement system.

velocity on the rocks is calculated dividing the sample length $(\Delta x)$ by the time $(\Delta t)$ effectively spent by the wave on the sample:

$$
V=\frac{\Delta x}{\Delta t} .
$$

It is important to observe that the time effectively spent by the wave on the sample $(\Delta t)$ is equal to the time observed in the oscilloscope minus the system time or the delay time $t_{o}(\Delta t=$ $t-t_{o}$ ), where $t_{o}$ is the time spent by the signal in the electronic part andon the metallic caps when there is no sample inserted in the system, which means, it is the intrinsic system delay time.

The most traditional method of estimate the transit time is the picking of a determined event, as the first break or the maximum of the first peak. In the literature, the transit time estimative is done by the reading of the time of the first break, which means, the time of the first oscillatory energy that crosses the sample is the most commonly used method. However, not always the first break is an easy event to identify due to the presence of noise or other 


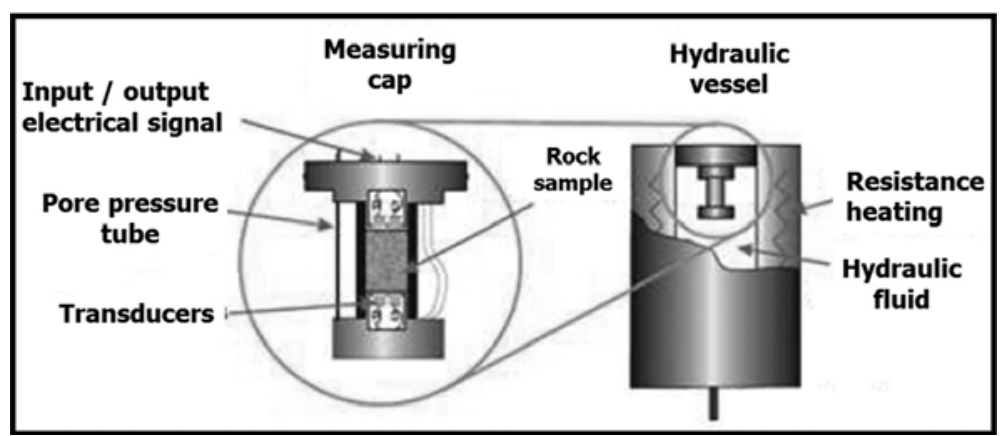

Figure 2 - Illustration on the hydraulic part of the elastic speed measure system in rock samples. Source: Laboratório de Física de Rochas from Cenpes (Petrobras).

interferences in the signal, especially in heterogeneous samples. That is why, in this paper, the transit time estimative was done using as reference, the time of the first peak after the first break to $P$ wave and the time of the first valley after the first break to $S$ wave. Considering the uncertainties associated to time and length measure, the error in these velocity measurements is of the order of 1\% to 2\% (Morschbacher et al., 2010).

\section{RESULTS AND DISCUSSIONS}

In order to establish the correlation between the elastic wave's propagation velocity and the rocks' characteristics, it has been made tests of density and porosity of grains in the Laboratorio de Física de Rochas from Cenpes (Petrobras).

Table 2 presents the porosity and density results obtained from the samples.

\section{Results from the Measurement of P Wave, S1 Wave and S2 Wave Velocities}

The wave transit time was measured increasing the pressure in $500 \mathrm{psi}$ steps until it reaches $5000 \mathrm{psi}$ and with a posterior decrease of pressure from 5000 psi down to 500 psi, also done in $500 \mathrm{psi}$ steps. Then, the velocity propagation of the compressional and shear waves was calculated using the Equation 1.

From the transit time data acquired and with the support of Matlab program, it was possible to represent the wave forms obtained on the samples in study, in a similar way of a seismogram. Figure 3 illustrates an example to each form of $P$ wave, S1 and S2 waves obtained on a Berea sandstone sample, particularly (BRS001). This procedure described to a BRS001 sample was made to all of the 15 samples, obtaining the P, S1 and S2 waves velocities.

Based on the graphs obtained, it was possible to observe that, at lower pressures, the recorded signal amplitude diminishes and also the definition of the wave first arrival becomes less clear, especially for the shear waves. For this reason, the correlations made with $V_{p}$ and $V_{S}$ data refers to the highest applied pressure (5000 psi).

\section{Relationship between S1 Wave and S2 Wave Propagation Velocities}

The measurement of the propagation velocity of two shear waves with orthogonal polarization, traveling along the core longitudinal axis, is not sufficient for the characterization of the elastic anisotropy, but may give some insight on this phenomenon.

Using the values obtained to both $S$ waves measured, it has been done the calculation of the anisotropy degree from the samples applying the Equation 2.

$$
\frac{V S_{\text {fast }}-V S_{\text {slow }}}{V S_{\text {average }}} \times 100
$$

Figure 4 represents the dispersion diagram for the measured data between the fastest $S$ wave against the slowest $S$ wave to the three kinds of samples at 5000 psi pressure. Generally, the anisotropy degree is below $2 \%$ (of the order of the experimental error admitted for such type of measurement), indicating that the samples may be considered isotropic.

In general the S1 wave polarization was oriented with the bedding plane and, in fact, in the Berea sandstone samples, this was the fast shear wave direction. However, due to the absence of apparent bedding on the carbonates, it was eventually observed that the S2 were the fast direction in some samples of Silurian dolomite and Indiana limestone.

Therefore, to the correlations, the average between the $S 1$ and S2 wave velocity was used, assuming that it is possible to consider the rocks as isotropic. 
Table 2 - Porosity and Specific Mass obtained in the laboratory - Cenpes (Petrobras).

\begin{tabular}{|c|c|c|c|}
\hline Rock & $\begin{array}{c}\text { Sample } \\
\text { (Identification) }\end{array}$ & $\begin{array}{c}\text { Effective Porosity } \\
(\%)\end{array}$ & $\begin{array}{c}\text { Grain Specific Mass } \\
\left(\mathrm{g} / \mathrm{cm}^{3}\right)\end{array}$ \\
\hline \multirow{5}{*}{ Berea } & BRS001 & 18.8 & 2.65 \\
Sandstone & BRS002 & 18.7 & 2.65 \\
& BRS003 & 18.5 & 2.66 \\
& BRS016 & 18.9 & 2.66 \\
& BRS017 & 19.0 & 2.65 \\
\hline \multirow{5}{*}{ Indiana } & IL011 & 17.2 & 2.67 \\
& IL012 & 17.0 & 2.68 \\
& IL013 & 15.8 & 2.69 \\
& IL016 & 15.2 & 2.69 \\
& IL017 & 13.7 & 2.68 \\
\hline \multirow{5}{*}{ Silurian } & SD005 & 11.0 & 2.72 \\
Dolomite & SD006 & 16.1 & 2.81 \\
& SD007 & 14.2 & 2.82 \\
& SD010 & 16.7 & 2.83 \\
& SD011 & 18.2 & 2.83 \\
\hline
\end{tabular}
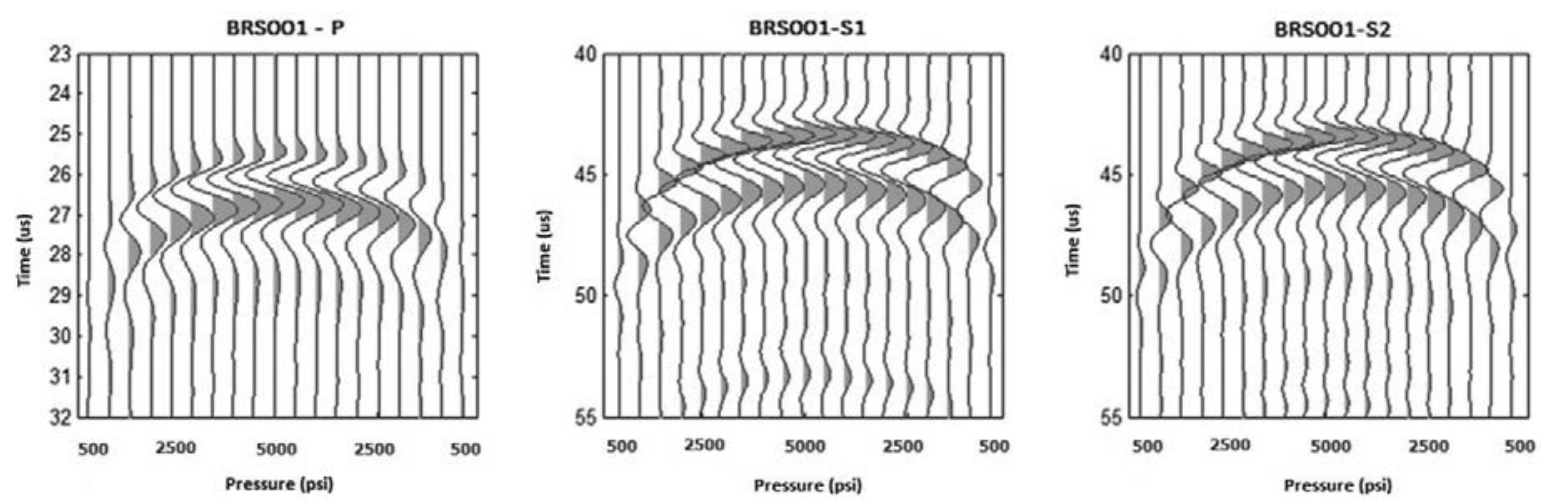

Figure 3 - Example of compressional and shear waves recorded at different pressures for sample BRS001.

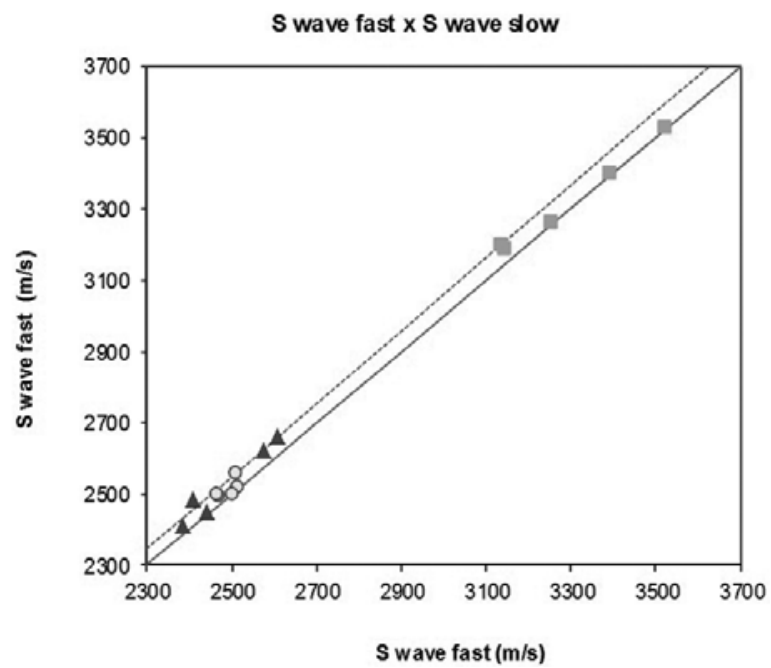

Figure 4 - Dispersion diagram for the fast and slow S wave velocities at 5000 psi pressure for the sandstone (yellow circles), carbonate (blue triangles) and dolomite (green squares) samples. The continuous red line represents the identity and the dashed line a difference of $2 \%$. 

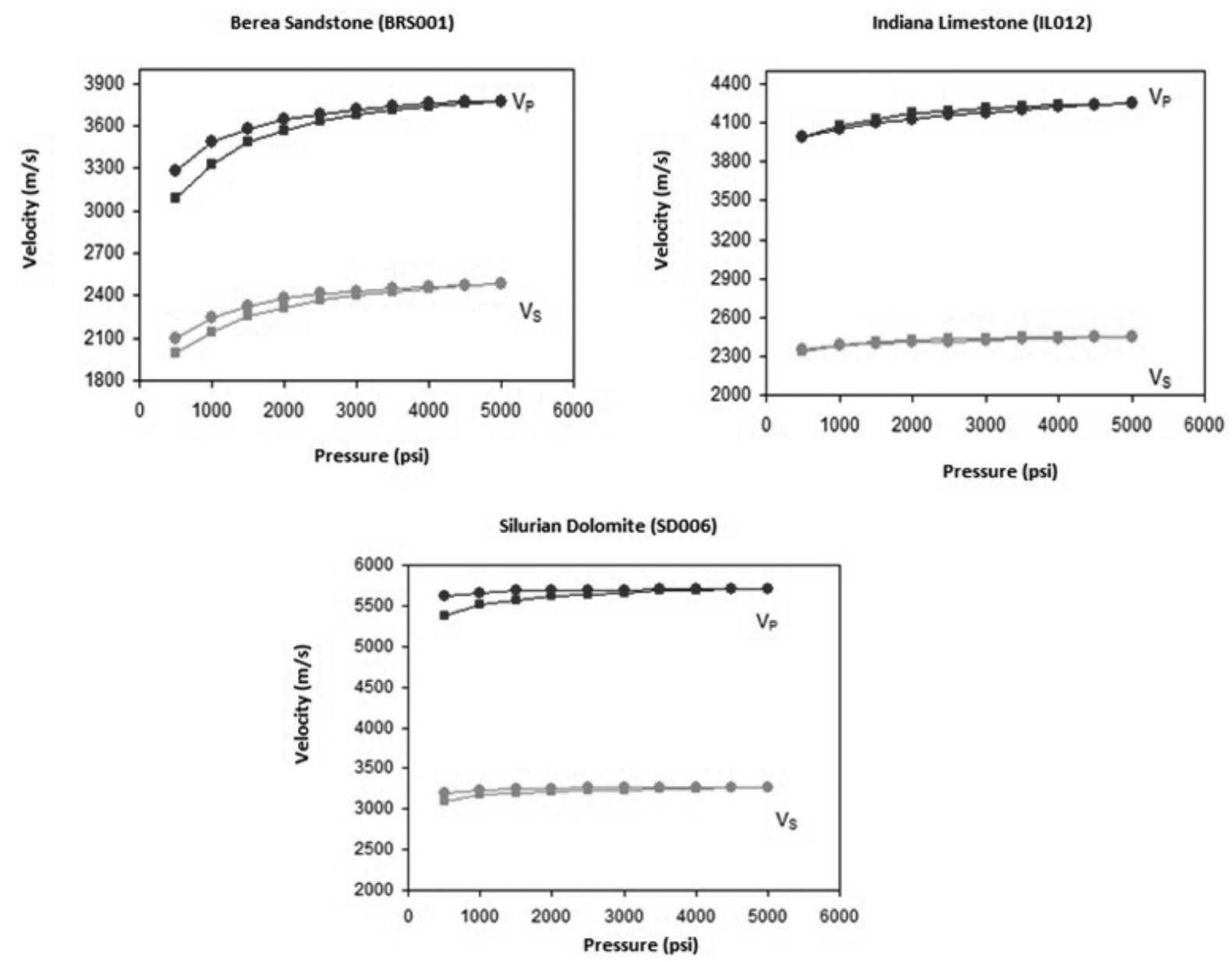

Figure 5 - The relation between the P, S1 and S2 wave propagation velocities with pressure variation for one sample of Berea Sandstone (BRS001), one sample of Indiana Limestone (IL012) and a sample of Silurian Dolomite (SD006). The data marked by squares represent the velocity measure with the increase of pressure and the data marked by circles represent the measure of velocity with pressure decrease.

\section{Variation of Elastic Wave Velocity of the Elastic Waves} with Pressure

The compressional and shear wave velocities increase with the increasing of the effective pressure, due to the closure of the microcracks of the rock. In sedimentary rocks, the velocities tend to asymptotic values at high applied pressures (Abreu, 2010). The tests made these characteristics evident. Figure 5 illustrates the trend of compressional and shear waves with the pressure variation, obtained on sample of each lithology.

For all the samples measured, it was observed similar trends. It is interesting noticing the phenomenon of hysteresis more evident in the sandstone, because when measuring the velocity with increasing pressure, it was obtained lower velocity values than the ones measured with the pressure decreasing to the same points. Which means, after the rock has been submitted to a pressure increase, the elastic properties behavior suffer a light alteration and with this, the $\mathrm{P}$ wave velocity at $3500 \mathrm{psi}$, for example, during the pressure increase is different from the obtained $\mathrm{P}$ wave velocity submitted at the same 3500 psi during the stress relief. In carbonates and dolomite rocks, the hysteresis phenomenon is observed in a lower intensity. These differences in hysteresis may be due to the compaction of the sandstone in the laboratory, closing grain contacts and small defects, which did not open as the stress was relieved. As the carbonates are more stiff and cemented compared to the Berea sandstones, they did not exhibit appreciable hysteresis.

Although it did not happened a perfect coincidence of velocity values on the up going cycles, and in the stress relief cycles, the hysteresis effects can be considered as second order effect, generally, because it was not observed any marked variations in the results. 


\section{Relation $\mathbf{V}_{\mathrm{P}} \mathbf{V}_{\mathrm{S}} \times \mathbf{V}_{\mathbf{P}}$}

One of the first accomplished works with the objective to discriminate rocks' lithology based on the ratio between the acoustic wave propagation velocities was Pickett's (1963). On this study, the quoted author concluded that the rocks with different porosities have different $V_{P} / V_{S}$ ratios, clean sandstones present ratio $V_{P} / V_{S}$ between 1.6 and 1.7, while limestones showed values of 1.9 and dolomites of 1.8. The $V_{P} / N_{S}$ ratio is a good lithologic indicator, because does not depend on the rock's density, while analyzing only a $\mathrm{P}$ wave velocity, the lithology indicator could be considered ambiguous, once $V_{p}$ is a function of density- $\rho$ of bulk modulus- $K$ and shear modulus- $\mu$ (Kearey et al., 2009). Although this study has been done with few samples, it was possible to find $V_{p} / V_{S}$ ratio values very close to the ones foreseen by Pickett (1963), on average, 1.52 to sandstone, 1.75 to carbonate and 1.77 to dolomite (Fig. 6).

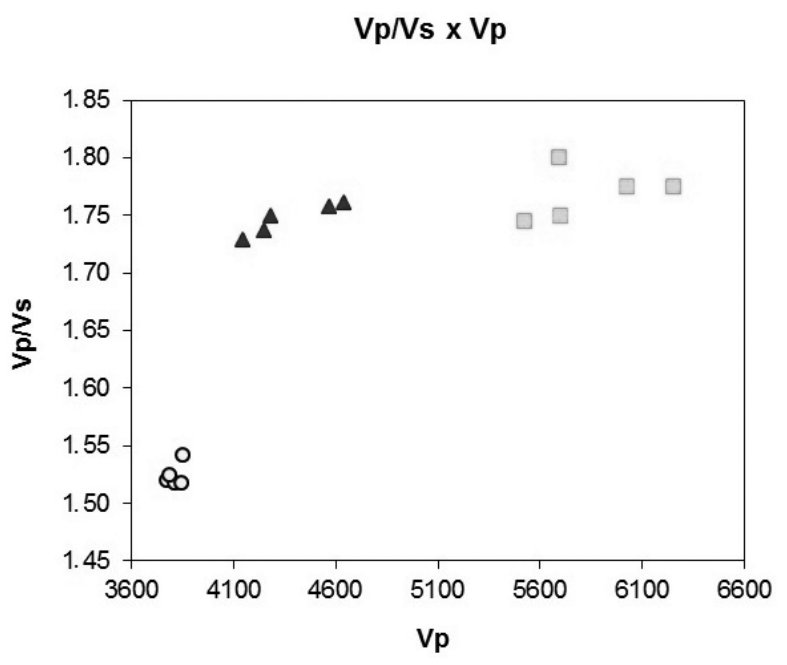

Figure 6 - Diagram of the $V_{p} N_{S} \times V_{p}$ relations obtained to the Berea Sandstone (circles), Indiana Limestone (triangles) and Silurian Dolomite (squares).

\section{Relation between $\mathbf{P}$ Wave Propagation Velocity and Porosity}

Using the data of compressional wave propagation velocity and porosity, it was possible to establish a relationship between these parameters (Fig. 7). It was noted that the data referring to Berea sandstone are less scattered, due to the fact that this rock presents very low porosity variation. For the Indiana limestone and Silurian dolomite, the data are more spread, but in general, it is possible to notice a trend to the decrease of the compressional wave velocity values with the porosity increase.

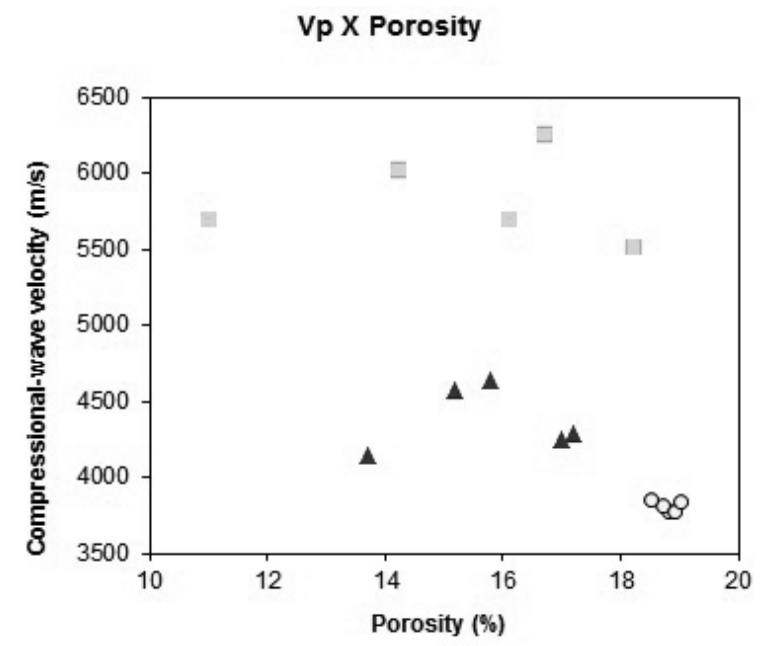

Figure 7 - Diagram of the $V_{p}$ relation to porosity obtained to the samples of Berea Sandstone (circles), Indiana Limestone (triangles) and Silurian Dolomite (squares). The further points, referring to samples SD005 and IL017, can be considered outliers; possibly, there was some sort of interference during the measurement.

\section{Elastic Wave Propagation Velocity and Fluid Substitution}

One of the most relevant problems in the study of rock physics is the seismic velocity estimative in rocks saturated with different fluids, the so called fluid substitution problem (Mavko et al., 1998). This happens because the type of fluid (gas, oil or water) present in the pores influences the elastic properties of a rock in different ways. Usually, when a rock is under a compressive effect, there is an increase of pore pressure, to which it resists to the compression and, therefore, hardens the rock (Smith et al., 2003).

The fluid substitution technique most widely used is based on the Biot-Gassmann theory, because it allows the simulation of the elastic behavior of the rocks under different saturation conditions (Smith etal., 2003). Gasmann (1951 apud Abreu, 2010) proposed an equation to calculate the bulk modulus $\left(K_{S A T}\right)$ of a saturated porous media from parameters known from the dry rock such as bulk modulus of the dry rock and of the solid matrix, the fluid and the porosity of the media. This way, the Gassmann theory foresees a resulting increase in the effective bulk modulus, $K_{S A T}$, of a saturated rock throughout the following equation (Gassmann, 1951 apud Abreu, 2010):

$$
K_{S A T}=K_{D R Y}+\frac{\left(1-\frac{K_{D R Y}}{K_{G}}\right)^{2}}{\frac{\phi}{K_{F}}+\frac{(1-\phi)}{K_{G}}+\frac{K_{D R Y}}{K_{G}^{2}}}
$$

where:

$K_{S A T}=$ saturated rock bulk modulus; 
$K_{D R Y}=$ dry rock bulk modulus;

$K_{F}=$ fluid bulk modulus or incompressibility;

$K_{G}=$ solid matrix bulk modulus; and

$\phi=$ porosity.

The dry rock parameters necessary to calculate the saturated rock bulk modulus can be obtained by measuring the dry rock velocities in laboratory. Considering that the rock shear modulus does not change with saturation (Gassmann, 1951), the wave velocities foreseen by Gassmann are given as:

$$
V_{P, S A T}=\sqrt{\frac{K_{S A T}+\frac{4}{3} \mu}{\rho_{S A T}}}
$$

and

$$
V_{S, S A T}=\sqrt{\frac{\mu}{\rho_{S A T}}}
$$

In order to observe the influence of rock saturation in the compressional and shear wave propagation, 3 samples were saturated with water, one of each lithology, and then, it has been performed new $V_{p}$ and $V_{S}$ measurements. The chosen samples were BRS002, SD006 and IL013. In parallel, it has been performed also an estimative of $V_{p}$ and $V_{s}$ for the saturated rocks from the Gassmann equation (Eq. 3). To use this model, it has been adopted some values on the table of mineral bulk modulus (Table 3) and for the water bulk modulus, it was considered a value of $2.25 \mathrm{GPa}$ (Mavko et al., 1998).

Table 3 - Average values of the density and elastic moduli to some sort of minerals.

\begin{tabular}{|c|c|c|c|}
\hline Mineral & $\begin{array}{c}\text { Density } \\
\left(\mathrm{g} / \mathrm{cm}^{3}\right)\end{array}$ & $\begin{array}{c}\text { Bulk Moduli } \\
(\mathrm{GPa})\end{array}$ & $\begin{array}{c}\text { Shear Moduli } \\
(\mathrm{GPa})\end{array}$ \\
\hline Quartz & 2.65 & 36.6 & 45 \\
Calcite & 2.71 & 76.8 & 32 \\
Dolomite & 2.87 & 94.9 & 45 \\
\hline
\end{tabular}

Figure 8 indicates the results obtained for $V_{p}$ and $V_{S}$ for dry and saturated rock, compared to the forecast made by the Gassmann model.

It was noted that the presence of fluids in the pore spaces affects the elastic properties of the rocks and, consequently, will affect its seismic signature. In the sandstone samples, which present more porosity, the effect is even greater. In a general way, the compressional velocity in rocks saturated with water is higher than the compressional velocity in dry rocks. To the shear wave velocity, it is observed the contrary; the addiction of fluid reduces the shear wave velocity, because the shear modulus remains (unchanged) unaltered while the density increases. The forecast to
$\mathrm{P}$ and $\mathrm{S}$ waves velocity done with Gassmann's equations presented satisfactory results, with high precision data and errors lower than $3 \%$, even without respecting the theory assumption of low frequencies to accomplish the measurements (Gasmann, 1951), once that in the laboratory, high frequencies are used. It is also interesting to point out that the Gassmann's model worked as well on the carbonate rocks as on the sandstone. The average error for Berea sandstone, Indiana limestone and Silurian dolomite were respectively $1.4,0.5$ and $1.2 \%$ for $P$ wave and 3.8 , 3.3 and $2.6 \%$ for $S$ wave.

\section{CONCLUSION}

With these results, it was possible to study the correlations between the types of lithology and the of the elastic wave propagation velocity, as well as to verify the influence of factors such as porosity, pressure and presence of saturating fluid in the elastic behavior of the rock.

The velocity measurement under loading and unloading stress paths revealed some hysteresis effect that may be associated with a compaction of the rocks on the laboratory. Although these effects were generally small, the Berea sandstone presented more pronounced effect compared with the carbonate rocks, probably because it is relatively less cemented and stiff compared to the carbonates.

The estimative of compressional and shear wave velocities of saturated rocks from data measured on dry rocks using the Gassmann equations were very close to the values determined experimentally (as indicated on Fig. 8), which assures the efficiency of this methodology to the study of the effect of the replacement of fluids in the seismic behavior of wells. The average relative errors were less than $1.5 \%$ for $P$ wave and $3.8 \%$ for $S$ wave velocities. This indicates, also, the importance of the empirical results in the verification of the validity of theories and proposed models.

It is evident that the physical properties of the rocks from laboratory measurements contribute to the establishment of relations between these properties and the seismic signature of the rock and, consequently, it has many important applications to the enhancement of the seismic method. The understanding of these relations is crucial to better the interpretation of geophysical measures.

\section{ACKNOWLEDGEMENTS}

The authors thank all the crew and staff of the Laboratório de Física de Rochas from Cenpes (Petrobras), specially the technicians Tagore Ostape, Guilherme Sollo and Marcos Leão for the support during the accomplishment of the tests and also thank the Geophysicist Márcio J. Morschbacher for the orientation and guidance over the result discussions. 

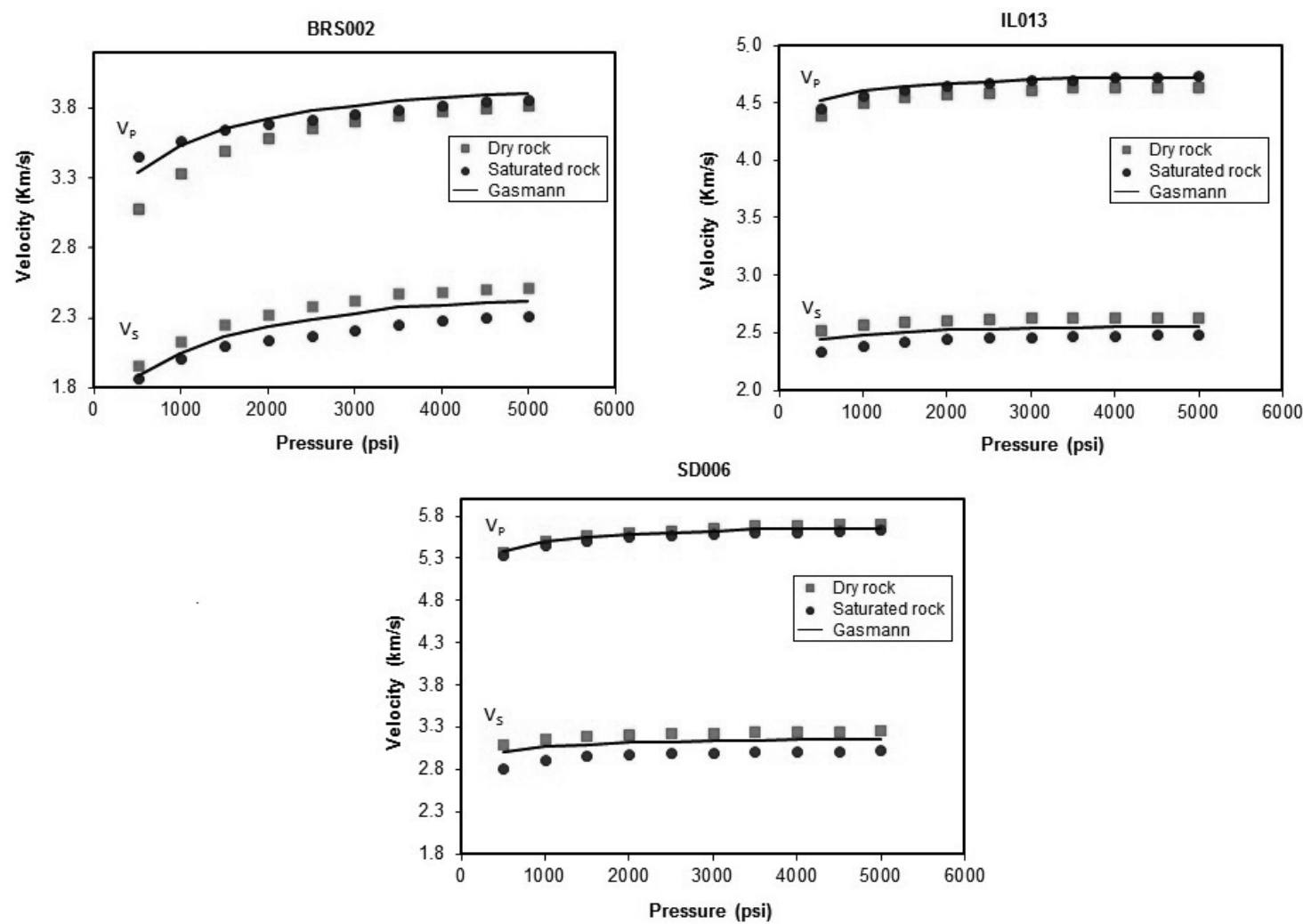

Figure 8 - Velocity of the samples BRS002 (Berea Sandstone), IL013 (Indiana Limestone), and SD006 (Silurian Dolomite) dry and saturated with water, compared to Gassmann's forecast.

\section{REFERENCES}

ABREU ES. 2010. Theoretical Modeling and Empirical Research applied to the connection between the petrophysical properties and Elastic in carbonate rocks. Master Thesis, UNICAMP, São Paulo, Brazil, 129 pp.

ARCHILHAN, CEIA M, MISSÁGIAR \& LIMA NETO I. 2012. Comparação entre as constantes elásticas estimadas pelas velocidades e pela composição mineral de rochas carbonáticas. In: Brazilian Symposium on Geophysics, 5., Salvador. Proceedings... Salvador, Brazil: SBGf, 2012, CD-ROM.

DILLON LD \& VASQUEZ GF. 2000. Física de Rochas: Fundamentos e Aplicações. Handbook Petrobras, 67 pp.

GASSMANN F. 1951. Elastic Waves through a Packing of Spheres. Geophysics, 16: 673-685.

HILLEBRAND LB \& COOGAN AH. 1984. Berea Sandstone Reservoirs in Ashland and Medina Counties. Ohio, Conference: AAPG Eastern Section Meeting. Pittsburgh, PA, USA, Journal, 68(12): 1920.

ISGS - Illinois State Geological Survey. Mississippian Rocks in Illinois. Available on: <http://www.isgs.illinois.edu/outreach/geology- resources/mississippian-rocks-illinois $>$. Prairie Research Institute. Access on: June 10, 2013.

KEAREY P, BROOKS M \& HILL I. 2009. Geofísica de Exploração. Editora Oficina de Textos: São Paulo, Brazil. 438 pp.

MAVKO G, MUKERJI T \& DVORKIN J. 1998. The Rock Physics Handbook: Tools for Seismic Analysis in Porous Media. Cambridge University Press, Cambridge, New York, USA, 329 pp.

MORSCHBACHER M, VASQUEZ G \& JUSTEN J. 2010. Metodologias de estimativa das velocidades sísmicas em ensaios de laboratório. In: SimBGF IV (Brazilian Symposium on Geophysics), 4., Brasília, DF, Brazil, CD-ROM.

PICKETT GR. 1963. Acoustic character logs and their application in formation evaluation. Journal of Petroleum Technology, 15: 659-667.

SMITH TM, SONDERGELDZ CH \& RAI CS. 2003. Gassmann fluid substitutions: A tutorial. Geophysics, 68(2): 430-440.

USGS - U.S. Geological Survey. Contributions to the Geology of Kentucky/Silurian System. Available on: < http://pubs.usgs.gov/pp/p1151h/ silurian.html>. Access on: June 10, 2013. 


\section{NOTES ABOUT THE AUTHORS}

Ana Paula Oliveira Castro. Holds a BSc in Physics from the Universidade Federal da Bahia, Brazil, 2007. Degree in Geophysics from Universidade Federal Fluminense, Brazil, 2013. Currently serves as a technician in chemistry at Petrobras, in the area of research on the technique of ion chromatography for process water and water produced.

Eliane da Costa Alves. Holds a BSc in Geology from Universidade Federal do Rio de Janeiro, MSc in Marine Geology from Universidade Federal do Rio Grande do Sul and DSc in Geology/Geophysics from Universidade Federal do Rio de Janeiro, shared with University of Western Brittany, Plouzané/France. Professor of the Universidade Federal Fluminense, since 1984. Main interest in the significance of the extension of fracture zones for the continental margins and depositional processes and structures of marginal basins, salt tectonics, depositional systems in deep waters, seabed stability and petroleum system modeling.

Guilherme Fernandes Vasquez. Holds a BSc in Physics from Universidade Federal do Rio de Janeiro, MSc in Reservoir Engineering from Universidade Estadual de Campinas and DSc in Geology from Universidade Federal do Rio de Janeiro. Main interest is rock physics and its relation to seismic hydrocarbon detection. Works for Petrobras since 1990 dedicated mainly to the Rock Physics Laboratory of the Petrobras Research Center (Cenpes), conducting research projects and technical assistance, and now holds the position of senior geophysicists and senior advisor. 